\title{
In Vitro Studies of Sodium Transport in Human Infant Colon: The Influence of Acetate
}

\author{
H. R. JENKINS, U. SCHNACKENBERG, AND P. J. MILLA \\ Institute of Child Heath, Londen, United Kingdom
}

\begin{abstract}
In infants, adequate colonic function is vital in preventing electrolyte and water depletion. In certain species, short-chain fatty acids have been shown to increase colonic $\mathrm{Na}$ absorption. Using an in vitro voltage-clamp technique, we have studied the characteristics of electrolyte transport in isolated preparations of human left-sided colonic mucosa and investigated the effect of acetate on epithelial Na movement. In the basal state, there was net $\mathrm{Na}$ absorption that was entirely electrogenic. The addition of mucosal acetate resulted in a significant increase in net $\mathrm{Na}$ absorption that was markedly inhibited by amiloride, suggesting that, in the young child, the presence of shortchain fatty acids promotes colonic salvage of $\mathrm{Na}$ and that such salvage of $\mathrm{Na}$ may be via an amiloride-sensitive $\mathrm{Na}$ channel and involve stimulation of sodium-hydrogen exchange. (Pediatr Res 34: 666-669, 1993)
\end{abstract}

\section{Abbreviations}

SCFA, short-chain fatty acid

Ac, acetate

$G$, conductance

$P D$, potential difference

Isc, short-circuit current

Cl, chloride

JNanet, net flux of sodium ions

JNams, mucosa to serosa flux of sodium ions

Although it is clear that the majority of water and electrolyte absorption occurs in the small intestine, it is often the adequacy of colonic function that determines whether or not there is diarrhea and consequent net loss of water and electrolytes from the body (1). In vivo studies in both the experimental animal (24) and the human colon (5-8) have established that $\mathrm{Na}$ and $\mathrm{Cl}$ are absorbed and that $\mathrm{K}$ and $\mathrm{HCO}_{3}$ are secreted. In vitro studies, in which both the chemical and spontaneous electrical gradients are controlled, have provided important additional information regarding the mechanisms responsible for electrolyte movement across colonic epithelia in the adult human $(9-16)$.

SCFA, which are produced by colonic bacterial fermentation of dietary carbohydrates, are the principal anions found in the colon of several mammalian species and may be important in the salvage of both calories and electrolytes. Indeed, they influence colonic electrolyte transport (17-24), and in vivo studies have provided evidence that SCFA are rapidly absorbed from the colon of man (25) and that they can promote $\mathrm{Na}$ and water absorption from the colon $(26,27)$.

The only data on possible mechanisms of colonic salt and

Received January 17, 1992; accepted June 1, 1993.

Correspondence: Dr. H. R. Jenkins, Department of Child Health. University Hospital of Wales, Heath Park, Cardiff, CF4 4XW, United Kingdom.

H.R.J. was the recipient of an Action Research Training Fellowship. water absorption in human infants are derived from in vivo studies where electrical gradients influence ion movements and chemical gradients are uncontrolled (8). The purpose of our present study was to carry out a more detailed analysis of $\mathrm{Na}$ transport in isolated human infant colon using a voltage clamp technique in an Ussing chamber, and also to investigate the effect on colonic $\mathrm{Na}$ absorption of adding mucosal Ac.

\section{MATERIALS AND METHODS}

IIuman colon preparation. Colonic tissue was obtained from children undergoing colonic operation for Hirschsprung's disease or anal atresia at the Hospital for Sick Children. Tissue whose resistance was lower than $90 \mathrm{ohms} / \mathrm{cm}^{2}$ was discarded. Ten tissue pairs were studied from the left colons of eight different children, aged 10-20 mo (four with Hirschsprung's disease and four with anal atresia). The segments of descending colon, of lengths varying from 4 to $20 \mathrm{~cm}$, were removed by the surgeon immediately after compromising the blood supply and then opened along the mesenteric border and immersed in iced, preoxygenated Krebs-Hensleit solution. Muscle coats were removed from the intestine, as previously described, before mounting in the chambers.

The specimens of mucosa, which were all macroscopically normal (confirmed by subsequent histologic examination), were then mounted between two Perspex half chambers within 10-15 min of removal from the body, as previously described (28). An area of $0.64 \mathrm{~cm}^{2}$ of each surface of the mucosa was exposed to $15 \mathrm{~mL}$ of Krebs-Hensleit bathing solution containing Na $143, \mathrm{~K}$ $5.9, \mathrm{Ca} 1.9, \mathrm{Mg} \mathrm{1.1}, \mathrm{Cl} 129, \mathrm{HPO}_{4}$ 1.2. $\mathrm{HCO}_{3} 25$, and glucose $10 \mathrm{mmol} / \mathrm{L}(\mathrm{pH} 7.0)$. The solutions were maintained at $37^{\circ} \mathrm{C}$ by heated water jackets and were oxygenated and circulated via a bubble-lift mechanism containing a $95 \% \mathrm{O}_{2}-5 \% \mathrm{CO}_{2}$ mixture.

Electrical measurements. The spontaneous transmucosal electrical PD was measured through 2\% agar-salt bridges containing Krebs-Hensleit solution connected to a high-impedance digital voltmeter (Analogic AN 2570) via matched calomel electrodes (asymmetric potential $\pm 0.2 \mathrm{mV}$ ) immersed in $3 \mathrm{M} \mathrm{KCl}$. The combined electrode and bridge junction potentials did not exceed $0.5 \mathrm{mV}$. The mucosa was short-circuited by a current (Isc) passed from an external dry battery via $\mathrm{Ag} / \mathrm{Ag} \mathrm{Cl}$ electrodes and agar salt bridges placed at opposite ends of the half chambers. The current was adjusted manually every $2-3 \mathrm{~min}$ and a correction was made for the drop in potential caused by the resistance of the fluid gap between the PD electrode tips, as described by Field et al. (29).

The electrical resistance of the mucosa, and thus $G$, was determined by passing a pulse of direct current of $100 \mu \mathrm{A}$ and correcting the change in PD for fluid resistance. An initial fall in PD of $2-3 \mathrm{mV}$ occurred after mounting the tissue in the chamber, but after $20 \mathrm{~min} P D$, Isc, and $G$ had reached values that remained stable for $180 \mathrm{~min}$ before gradually declining.

Radioisotope fluxes. Fluxes of radiolabeled Na were measured on paired tissues taken from adjacent segments of colon, and either two or four specimens were set up for each experiment. 
Tissues whose electrical resistance differed by less than $25 \%$ were paired to determine unidirectional fluxes. Twenty $\min$ after mounting the tissue to the mucosal reservoir of one chamber and to the serosal reservoir of the other chamber for each pair of tissues, $2.2 \mu \mathrm{Ci}$ of each isotope were added. The tissues were then short-circuited for $20 \mathrm{~min}$, after which a $2-\mathrm{mL}$ sample was removed from each unlabeled bathing solution and a $100-\mu \mathrm{L}$ sample from each labeled solution. Samples removed from the unlabeled solution were replaced by an equal volume of the appropriate unlabeled bathing solution. Duplicate samples were taken 20 min later to determine baseline flux rates.

After this, in four pairs of tissue, amiloride $10^{-4} \mathrm{M}$ was added to the mucosal surface and, after a further 20 -min equilibration period, flux experiments were again performed. In the other six pairs of tissue, after the basal flux experiments had been completed, the original bathing solution on the mucosal side of the tissues was replaced by a solution containing $60 \mathrm{mmol}$ of Ac and $69 \mathrm{mmol}$ of $\mathrm{Cl}$, the composition of the fluid being otherwise identical to the original solution. After a 20 -min equilibration period, further $\mathrm{Na}$ flux experiments were performed replacing the samples taken with solutions of appropriate electrolyte content. Amiloride $10^{-4} \mathrm{M}$ was then added to the mucosal surface and, after a further 20-min equilibration period, final $\mathrm{Na}$ flux experiments were undertaken.

The samples were counted and calculations were performed as described by Booth et al. (28). All values are expressed as median (range) and, in experiments involving both Ac and amiloride, statistical comparisons were made using a modification of the multiple comparisons procedure of Friedman (30).

It is clear that in the experiments involving Ac both Ac and $\mathrm{Cl}$ are asymmetric across the tissue and gradients in opposite directions exist for each of them. $\mathrm{A} \mathrm{Cl}$ diffusion potential will obviously exist. However, it is unknown whether there is a significant diffusion of SCFA across human colon, and there are conflicting data from animal experiments $(31,32)$. If there is a significant diffusion of SCFA. then it might be expected that this would cancel out any diffusion potential generated by the passive diffusion of $\mathrm{Cl}$ ions in the opposite direction. We have thus expressed the results without taking into account any possible diffusion potential.

\section{RESULTS}

Table I shows the results of individual basal flux experiments in 10 pairs of left-sided colon, and Table 2 shows the flux results in four pairs of colon before and after the addition of mucosal amiloride.

It is clear that, under basal conditions, there was net $\mathrm{Na}$ absorption and JNanet closely approximated Isc. The addition of amiloride markedly reduced JNanet via an effect on JNams and almost abolished Isc, with a concomitant fall in G. These results suggest that $\mathrm{Na}$ absorption in infant left colon under basal conditions occurs largely via an electrogenic, amiloride-sensitive pathway that can account almost entirely for the measured Isc.

Table 3 shows the results obtained from $\mathrm{Na}$ flux experiments expressed as median (range) in six pairs of tissue, first under basal conditions, then after the addition of mucosal Ac $60 \times$ $10^{-3} \mathrm{M}$ and again after the addition of mucosal amiloride $10^{-4}$ M. After the addition of Ac there was a highly significant increase in $\mathrm{Na}$ absorption, due entirely to an increase in JNams. There was no change in Isc or PD. The addition of amiloride reduced JNams (and thus JNanet) to levels seen in the basal state before the addition of acetate and resulted in a reduction in Isc and PD.

\section{DISCUSSION}

The large intestine plays a particular role in the salvage of salt. water, and partially digested nutrients. In infancy, colonic transport mechanisms are particularly important in Na conservation (8), but no in vitro systematic studies of colonic $\mathrm{Na}$ absorption have been previously undertaken in childhood. A recent study has reported that the mechanism of $\mathrm{Na}$ absorption may vary in different parts of the colon (14), but unfortunately we were only able to obtain satisfactory tissue from the left side of the colon.

In viro perfusion studies in adult humans have suggested that SCFA, derived from bacterial fermentation of carbohydrate, may promote $\mathrm{Na}$ and water absorption, but this has not been previously demonstrated in vitro nor has the mechanism been defined. However, in vitro studies of adult human colon (9-16) have shown that there is active $\mathrm{Na}$ absorption that may entirely account for the Isc $(12,14)$, although some studies observed that JNanet may be greater than Isc $(9-11,13,15)$. Our data show that JNanet approximates Isc and is largely abolished by amiloride, suggesting that, in infant descending colon, active $\mathrm{Na}$ absorption occurs mostly via an electrogenic, amiloride-sensitive process that is responsible for the generation of transmural PD and Isc. We have recently shown that rectal $\mathrm{Na}$ absorption in infants is closely related to circulating aldosterone levels (8). The finding of an electrogenic, amiloride-sensitive pathway in the present study is entirely in keeping with perhaps the major effect of aldosterone on colonic $\mathrm{Na}$ transport as an $\mathrm{Na}$ regulatory hormone (33).

Although four of the patients studied suffered from Hirschsprung's disease, it has been previously shown that aganglionic colon is an efficient absorptive epithelium (34) and our in vitro studies now confirm this. In our experiments, basal Isc and $G$ were similar to those reported in adult human colon, although PD was lower $(9-16)$.

Perfusion studies in adult colon have shown that Na absorption increased in the presence of SCFA in the lumen via a process as yet unexplained $(27,35)$. It has been postulated that this may occur via the recycling of $\mathrm{H}$ ions and the presence of an $\mathrm{Na} / \mathrm{H}$ antiporter. Our basal flux data show little evidence of such an antiporter because JNanet only slightly exceeds Isc. However, in our study it is possible that the stimulation of $\mathrm{Na}$ absorption

Table 1. Basal sodium flux, transepithelial PD, tissue $G$, and Isc in I0 pairs of human infant left colon*

\begin{tabular}{|c|c|c|c|c|c|c|}
\hline Pair & $\begin{array}{c}\mathrm{PD} \\
(\mathrm{mV})\end{array}$ & $\begin{array}{c}\mathrm{G} \\
\left(\mathrm{mS} / \mathrm{cm}^{2}\right)\end{array}$ & $\begin{array}{c}\text { Isc } \\
\left(\mu \mathrm{mol} / \mathrm{h} / \mathrm{cm}^{2}\right)\end{array}$ & $\begin{array}{c}\mathrm{Jms} \\
\left(\mu \mathrm{mol} / \mathrm{h} / \mathrm{cm}^{2}\right)\end{array}$ & $\begin{array}{c}\mathrm{Jsm} \\
\left(\mu \mathrm{mol} / \mathrm{h} / \mathrm{cm}^{2}\right)\end{array}$ & $\begin{array}{c}\text { Jnet } \\
\left(\mu \mathrm{mol} / \mathrm{h} / \mathrm{cm}^{2}\right)\end{array}$ \\
\hline 1 & 9.7 & 6.1 & 3.5 & 7.67 & 0.9 & +6.77 \\
\hline 2 & 7.9 & 9.4 & 4.61 & 7.58 & 1.43 & +6.15 \\
\hline 3 & 4.7 & 9.3 & 2.62 & 10.43 & 5.62 & +4.81 \\
\hline 4 & 7.7 & 8.3 & 3.56 & 7.84 & 3.31 & +4.53 \\
\hline 5 & 7.4 & 8.0 & 3.56 & 3.48 & 2.85 & +0.63 \\
\hline 6 & 7.3 & 10.9 & 4.55 & 8.66 & 7.61 & +1.05 \\
\hline 7 & 7.8 & 7.8 & 4.2 & 6.4 & 2.5 & +3.9 \\
\hline 8 & 8.1 & 7.3 & 3.9 & 8.32 & 5.91 & +2.41 \\
\hline 9 & 5.8 & 9.1 & 2.6 & 6.45 & 3.56 & +2.89 \\
\hline 10 & 7.1 & 9.0 & 2.9 & 6.47 & 2.87 & +3.6 \\
\hline Median values & 7.55 & 8.6 & 3.56 & 7.63 & 3.09 & +3.75 \\
\hline
\end{tabular}

* Jms. mucosa to serosa flux; Jsm, serosa to mucosa flux: Jnet, net flux: + , net absorption. 
Table 2. Na flux, PD, G, and Isc in four pairs of human infant left colon in basal (B) state and after addition of mucosal amiloride $10^{-4} \mathrm{M}(\mathrm{Am})^{*}$

\begin{tabular}{|c|c|c|c|c|c|c|}
\hline Pair & $\begin{array}{c}\mathrm{PD} \\
(\mathrm{mV})\end{array}$ & $\underset{\left(\mathrm{mS} / \mathrm{cm}^{2}\right)}{\mathrm{G}}$ & $\begin{array}{c}\text { Isc } \\
\left(\mu \mathrm{mol} / \mathrm{h} / \mathrm{cm}^{2}\right)\end{array}$ & $\begin{array}{c}\mathrm{Jms} \\
\left(\mu \mathrm{mol} / \mathrm{h} / \mathrm{cm}^{2}\right)\end{array}$ & $\begin{array}{c}\mathrm{Jsm} \\
\left(\mu \mathrm{mol} / \mathrm{h} / \mathrm{cm}^{2}\right)\end{array}$ & $\begin{array}{c}\text { Jnet } \\
\left(\mu \mathrm{mol} / \mathrm{h} / \mathrm{cm}^{2}\right) \dagger\end{array}$ \\
\hline \multicolumn{7}{|c|}{1} \\
\hline B & 7.8 & 7.8 & 4.2 & 6.4 & 2.5 & +3.9 \\
\hline $\mathrm{Am}$ & 2.3 & 6.6 & 0.9 & 4.2 & 2.8 & +1.4 \\
\hline \multicolumn{7}{|l|}{2} \\
\hline B & 8.1 & 7.3 & 3.9 & 8.32 & 5.91 & +2.41 \\
\hline $\mathrm{Am}$ & 3.5 & 5.8 & 0.4 & 5.6 & 5.69 & -0.09 \\
\hline \multicolumn{7}{|l|}{3} \\
\hline B & 5.8 & 9.1 & 2.6 & 6.45 & 3.56 & +2.89 \\
\hline $\mathrm{Am}$ & 2.4 & 7.2 & 0.1 & 3.4 & 3.68 & -0.28 \\
\hline \multicolumn{7}{|l|}{4} \\
\hline B & 7.1 & 9.0 & 2.9 & 6.47 & 2.87 & +3.6 \\
\hline $\mathrm{Am}$ & 2.6 & 6.8 & 0.2 & 3.7 & 3.43 & +0.27 \\
\hline \multicolumn{7}{|c|}{ Median values } \\
\hline B & 7.45 & 8.3 & 3.4 & 6.46 & 3.22 & +3.25 \\
\hline $\mathrm{Am}$ & 2.5 & 6.6 & 0.3 & 3.95 & 3.56 & +0.09 \\
\hline
\end{tabular}

* Abbreviations are the same as in Table 1 .

$++=$ net absorption, $-=$ net secretion.

Table 3. Na flux, PD, G, and Isc in six pairs of human infant left colon in basal state $(B)$, after addition of mucosal Ac $60 \times 10^{-3}$ $M$, and then after addition of imucosal amiloride $10^{-4} \mathrm{M}(\mathrm{Am})^{*}$

\begin{tabular}{|c|c|c|c|c|c|c|}
\hline & $\begin{array}{c}\mathrm{PD} \\
(\mathrm{mV})\end{array}$ & $\underset{\left(\mathrm{mS} / \mathrm{cm}^{2}\right)}{\mathrm{G}}$ & $\begin{array}{c}\text { Isc } \\
\left(\mu \mathrm{mol} / \mathrm{h} / \mathrm{cm}^{2}\right)\end{array}$ & $\begin{array}{c}\mathrm{Jms} \\
\left(\mu \mathrm{mol} / \mathrm{h} / \mathrm{cm}^{2}\right)\end{array}$ & $\begin{array}{c}\mathrm{Jsm} \\
\left(\mu \mathrm{mol} / \mathrm{h} / \mathrm{cm}^{2}\right)\end{array}$ & $\begin{array}{c}\mathrm{Jnet} \\
\left(\mu \mathrm{mol} / \mathrm{h} / \mathrm{cm}^{2}\right)\end{array}$ \\
\hline B & $\begin{array}{r}7.55 \\
(4.7-9.7)\end{array}$ & $\begin{array}{c}8.7 \\
(6.1-10.9)\end{array}$ & $\begin{array}{c}3.56 \\
(2.62-4.61)\end{array}$ & $\begin{array}{c}7.76 \\
(3.48-10.43)\end{array}$ & $\begin{array}{c}3.08 \\
(0.9-7.61)\end{array}$ & $\begin{array}{c}+4.67 \\
(+0.63-+6.77)\end{array}$ \\
\hline$A C$ & $\begin{array}{c}8.6 \\
(6.5-10.7)\end{array}$ & $\begin{array}{c}7.0 \\
(5-9.5)\end{array}$ & $\begin{array}{c}3.85 \\
(2.92-4.84)\end{array}$ & $\begin{array}{c}13.29 \\
(9.58-20.6)\end{array}$ & $\begin{array}{c}4.71 \\
(1.47-9.65)\end{array}$ & $\begin{array}{c}+9.17 \\
(-0.07-+16.1)\end{array}$ \\
\hline $\mathrm{Am}$ & $\begin{array}{c}3.6 \\
(0-7.8)\end{array}$ & $\begin{array}{c}6.5 \\
(5-8.3)\end{array}$ & $\begin{array}{c}1.34 \\
(0-3.56)\end{array}$ & $\begin{array}{c}8.31 \\
(3.73-10.85)\end{array}$ & $\begin{array}{c}5.36 \\
(1.48-9.1)\end{array}$ & $\begin{array}{c}+4.1 \\
(-5.37-+5.79)\end{array}$ \\
\hline $\begin{array}{l}p \mathrm{~B} \text { is } \mathrm{Ac} \\
p \mathrm{Ac} \text { is } \mathrm{Am}\end{array}$ & $\begin{array}{c}\text { NS } \\
<0.05\end{array}$ & $\begin{array}{l}\text { NS } \\
\text { NS }\end{array}$ & $\begin{array}{c}\mathrm{NS} \\
<0.05\end{array}$ & $\begin{array}{l}<0.05 \\
<0.05\end{array}$ & $\begin{array}{l}\text { NS } \\
\text { NS }\end{array}$ & $\begin{array}{l}<0.05 \\
<0.05\end{array}$ \\
\hline
\end{tabular}

* Results are shown as median and range and $p$ denotes the significance value between $B$ and $A c$ and then Ac and $A m$ results using the multiple comparisons procedure of Friedman. Abbreviations are the same as in Table 1.

seen in the presence of acetate might be due to the unmasking of $\mathrm{Na} / \mathrm{H}$ exchange, which might then operate in concert with the electrogenic $\mathrm{Na}$ absorption existing in the basal state. The addition of amiloride might then inhibit the electrogenic pathway for $\mathrm{Na}$ absorption with a lesser effect on $\mathrm{Na} / \mathrm{H}$ exchange and thus explain why amiloride only partially reduced, rather than abolished, JNanet.

A second hypothesis has been advanced to explain the effect of SCFA on Na absorption that suggests that the stimulation of $\mathrm{Na}$ transport relates to the ionic diffusion of $\mathrm{Ac}$ anions. Indeed, at the $\mathrm{pH}$ of both colonic luminal contents ( $\mathrm{pH} \mathrm{6-7)} \mathrm{and} \mathrm{the}$ microclimate of the epithelial cell ( $\mathrm{pH} \mathrm{5.8-6.0),} \mathrm{SCFA} \mathrm{(dissocia-}$ tion constant 4.8) will be dissociated. Our data are also consistent with this theory, because one explanation for the increased $\mathrm{Na}$ absorption is that an equivalent amount of $A c$ is absorbed with the $\mathrm{Na}$. If any $\mathrm{Cl}$ diffusion potential is balanced by an equal but opposite Ac diffusion potential, then the lack of change in PD and Isc is explicable using the above hypotheses. In the absence of definite data regarding the passive permeability of Ac across human childhood colonic epithelium and considering that data from animal studies are conflicting $(31,32)$, it is difficult to accurately interpret the $\mathrm{PD}$ and Isc recorded after the addition of Ac. It is, however, likely that stimulation of $\mathrm{Na} / \mathrm{H}$ exchange is involved, as has been shown in other animal experiments.

Thus, although the precise mechanism involved is unknown, there is no doubt that $\mathrm{Na}$ absorption by infant left colon occurs in the basal state largely by an amiloride-sensitive electrogenic Na-absorptive mechanism. The presence of mucosal acetate increases $\mathrm{Na}$ absorption probably by the stimulation of $\mathrm{Na} / \mathrm{H}$ exchange, which is not evident under basal study conditions. It is therefore clear that the bacterial metabolism of carbohydrate in the colon may be an important factor in the overall salvage of salt and water in the young infant.

Acknowledgme'mt. The authors thank Leah Gallivan for typing the manuscript.

\section{REFERENCES}

1. Read N 1982 Diarrhoca: the failure of colonic salvage. Lancet 2:481-483

2. Edmonds CJ 1967 Transport of sodium and secretion of potassium and bicarhonate by the colon of normal and sodium-depleted rats. J Physiol (Lond) 193:589-602

3. Edmonds CJ 1967 Transport of potassium by the colon of normal and sodiumdepleted rats. J Physiol (Lond) 193:603-617

4. Cuoperstein IL. Brockman SK 1954 The electrical potential difference generated by the large intestine: its relationship to electrolyte and water transfer. J Clin Invest 38:435-442

5. Devroede GJ, Phillips SF 1969 Conservation of sodium, chloride and water by the human colon. Gastroenterology 56:421-426

6. Edmonds CJ 1971 Absorption of sodium and water by human rectum measured by a dialysis method. Gut 12:356-362

7. Rask-Madsen J 1973 Simultaneous measurement of electrical polarization and clectrolyte transport by the entire normal and inflamed human colon during an in vive perfusion. Scand J Gastroenterol 8:327-336

8. Jenkins HR. Fenton TR. McIntosh N. Dillon MJ. Milla PJ 1990 Development of colonic sodium transport in early childhood and it regulation by aldosterone. Gut 31:194-197

9. Grady GF, Duhamel RC, Moore EW 1970 Active transport of sodium by human colon in vitro. Gastroenterology 59:58.3-588

10. Archampong EQ. Harris J. Clark CG 1972 The ahsorption and secretion of water and electrolytes across the healthy and the diseased human colonic mucosa measured in vitro. Gut 13:880-886

11. Rask-Madsen J. Hjelt K 1977 Effect of amiloride on electrical activity and electrolyte transport in human colon. Scand J Gastroenterol 12:1-6 
12. Hawker PC, Mashiter KE. Turnberg LA 1978 Mechanisms of transport of $\mathrm{Na}$, $\mathrm{Cl}$ and $\mathrm{K}$ in the human colon. Gastrocnterology $74: 1241-1247$

13. Kuwahara A. Cooke HJ. Carey HV. Mekhjan H. Ellison EC. McGregor B 1989 Effects of enteric neural stimulation on chloride transport in human left colon in vitro. Dig Dis Sci 34:206-213

14. Hubel KA. Renquist K. Shirazi S 1987 Ion transport in human cecum, transverse colon and sigmoid colon in vitro. Gastroenterology 92:501-507

15. Sellin JH. DeSoignie R 1987 Ion transport in human colon in vitro. Gastroenterology 93:969-976

16. Sandle GI, Higgs N, Crowe P. Marsh MN. Venkateson S, Peters TJ 1990) Cellular basis for defective electrolyte transport in inflamed human colon. Gastroenterology 99:97-105

17. Wrong OM, Metcalfi-Gibson A, Morison RBI. Ng St, Howard AV $1965 \mathrm{~m}$ vive dialysis of faeces as a method of stool analysis. Techniques and results in normal subjects. Clin Sci 28:357-375

18. Argenzio RA. Southworth M. Stevens CE 1974 Sites of organic acid production and absorption in the equine gastrointestinal tract. Am J Physiol 226:10431050

19. Henning SJ, ! Jird JRF 1970 Concentration and metabolism of volatile fatty acids in the fermentative organs of 2 species of kangaroo and the guinea-pig. Br J Nutr 24:146-155

20. Henning SJ, Hird FJ 1972 Transport of acetate and hutyrate in the hind-gut of rabbits. Biochem J 130:791-796

21. McNeil NI, Cummings JH. James WPT 1978 Short chain fatty acid absorption by the human large intestine. Gut 19:819-822

22. Argenzio RA, Whipp SC 1979 Interrelationship of sodium, chloride, bicarbonate and acetate transport by the colon of the pig. J Physiol (Lond) 295:365381

23. Argenzio RA, Miller N, von Engelhardt W 1975 Effect of volatile fatty acids on water and ion absorption from the goat colon. Am J Physiol 229:9971002

24. Unesaki Y. Yajima T, Yohokura T. Mutai M 1979 Effect of organic acid absorption on hicarbonate transport in rat colon. Ptlugers Arch 379:43-47

25. Roediger WEW. Rae DA 1982 Trophic effect of short chain fatty acids on mucosal handling of ions by the defunctioned colon. Br J Surg 69:23-25

26. Roediger WEW, Moore A 1981 Effect of short-chain fatty acid on sodium absorption in isolated human colon perfused through the vascular bed. Dig Dis Sci 26:100-106

27. Ruppin H, Bar-Meir S. Soergel KH, Wood CM, Schmitt MG 1980 Absorption of short-chain fatty acids by the colon. Gastroenterology 78:1500-1507

28. Booth IW. Milla PJ. Harries JT 1984 The effects of magnesium on ion transport in short-circuited rabbit terminal ileum. Clin Sci 66:465-471

29. Field M. Fromm D, McColl I 1971 Ion transport in rabbit ileal mucosa. Na and $\mathrm{Cl}$ fluxes and short circuit current. Am J Physiol 220:1388-1396

30. Siegel S, Castellan NJ 1988 Nonparametric Statistics for the Behavioural Sciences, 2nd Ed. McGraw-Hill International Editions. Maidenhead, UK

31. l.uciano L. Reale E. Rechkemmer G. Fngelhardt WV 1984 Structure of zonnulae occludentes and the permeability of the epithelium to short chain fatty acids in the proximal and the distal colon of guinea-pig. J Menbr Biol $82: 145-156$

32. Sellin JH1, DeSoignic R 1990 Short chain fatty acid absorption in rabbit colon in vitro. Gastroenterology 99:676-683

33. Sandle GI. Binder HJ 1987 Corticosteroids and intestinal jon transport. Gastroenterology 93:188-196

34. Heath AL. Spitz L. Milla PJ 1985 The absorptive function of colonic aganglionic intestine: are the Duhamel and Martin procedures rational'? J Pediatr Surg 20:34-36

35. Cummings Jll 1984 Colonic absorption: the importance of short chain fatty acids in man. Scand J Gastroenterol 19(suppl 93):89-99) 